Crop Breeding and Applied Biotechnology 10: 289-297, 2010

Brazilian Society of Plant Breeding. Printed in Brazil

\title{
Magnitude of the genetic base of commercial popcorn and in recommendation in Brazil
}

Thiago Otávio Mendes de Paula ${ }^{1}$, Leandro Simões Azeredo Gonçalves ${ }^{1}$, Antonio Teixeira do Amaral Júnior ${ }^{1 *}$, Érica Cristina de Oliveira $^{1}$, Vanessa Quitete Ribeiro da Silva ${ }^{1}$, Carlos Alberto Scapim ${ }^{2}$ and Ana Daniela Lopes ${ }^{2}$

Received 14 October 2009

Accepted 10 June 2010

ABSTRACT - The purpose of this study was to quantify the genetic diversity among popcorn genotypes on the market and in the final test phase, suitable for three environments in Brazil, based on 11 agronomic traits and ISSR markers. In the environment Campos dos Goytacazes a more reliable group formation was observed than in the other environments. The molecular data indicated the presence of cultivars recommended in the same group, as in the case of UFVM2 Barão de Viçosa, IAC 125, Zélia and Jade. This result is an appeal to the few popcorn breeders in Brazil to pay particular attention to increase the genetic diversity among breeding programs conducted by public and private institutions in the country. There was virtually no correlation between the distance matrix obtained by the ISSR marker and the matrices obtained by the agronomic data.

Key words: Zea mays, genotype-environment interaction, ISSR marker, multivariate analysis.

\section{INTRODUCTION}

In Brazil, popcorn cultivation has increased over the years due mainly to the increased consumption of natural popcorn and industry products thereof (Mora and Scapim 2007, Rinaldi et al. 2007, Catapatti et al. 2008, Rangel et al. 2008, Freitas Júnior et al. 2009). However, several studies of the Ministry of Agriculture have stated that the production is still limited compared to the market potential of the crop (Arnhold et al. 2009). The main restriction for the crop is the lack of options of cultivars with favorable agronomic characteristics and a high rate of popping expansion (Miranda et al. 2003, Rinaldi et al. 2007, Freitas Júnior et al. 2009, Mendes et al. 2010, Scapim et al. 2010).

The development of popcorn breeding programs designed to develop improved populations and/or hybrids adapted to Brazilian conditions is imperative to reduce the dependence on popcorn imports (Vilarinho et al. 2003, Leonello et al. 2009). Accordingly, the quantification of genetic variability, or in other words, the difference between the allelic counterparts of the expression of gene loci in a genotype group, is a cornerstone of plant breeding, be it to identify genetically distant genotypes, aiming to use distinct gene sets in crosses to obtain superior hybrids and segregating genotypes, or be it to assess the degree of genetic erosion or to know the size of the genetic base of cultivated forms (Miranda et al. 2003, Dandolini et al. 2008, Munhoz et al. 2009, Amaral Júnior et al. 2010, Leal et al. 2010, Silva et al. 2010).

The quantification of genetic diversity may be based on agronomic, morphological, biochemical, and molecular information, among others (Mohammadi and Prasanna

\footnotetext{
${ }^{1}$ Universidade Estadual do Norte Fluminense Darcy Ribeiro, Laboratório de Melhoramento Genético Vegetal, 28013-602, Campos dos Goytacazes, RJ, Brazil.*E-mail: amaraljr@uenf.br

${ }^{2}$ Universidade Estadual de Maringá, Departamento de Agronomia, 87020-900, Maringá, PR, Brazil.
} 
2003, Aguiar et al. 2008, Gonçalves et al. 2008, Leal et al. 2010). The agronomic traits are evaluated primarily by considering aspects of interest in terms of plant breeding and, lastly, of the producer himself, who is the ultimate beneficiary of this chain of information, which is also used for the final cultivar descriptions. However, the agronomic traits are usually strongly influenced by the environment and the genotype - environment (GE) interaction, adding yet another problem to factors underlying the breeder's decision on the selection of divergent genotypes.

Molecular markers, in turn, have advantages over other markers since genetic differences are shown in more detail and without the interferences caused by environmental effects, offering advantages in terms of discrimination and speed (Leal et al. 2010). Some studies have been conducted for a better understanding of diversity and relatedness between popcorn varieties using, e.g., RAPD (Vilela et al. 2008, Leal et al. 2010), ISSR (Kantety et al. 1995, Oliveira et al. 2010) and SSR (Li et al. 2004, Santacruz-Varela et al. 2004, Dandolini et al. 2008, Bracco et al. 2009, Munhoz et al. 2009, Silva et al. 2009, Leal et al. 2010).

This study aimed to: i) assess the environmental influence on estimates of genetic diversity using agronomic traits, ii) characterize and assess the extent of the genetic basis between commercial popcorn and in final test phase using agronomic and molecular traits, and iii) determine the association between distance matrices of agronomic and molecular data.

\section{MATERIAL AND METHODS}

\section{Genotypes}

Ten popcorn genotypes were evaluated BRS Angela, UFVM2 Barão de Viçosa, IAC 112, IAC 125, Zélia, Jade, Beija-Flor, Viçosa, UNB2U-C3, and UNB2U-C4 (Table 1).

\section{Agronomic traits}

Two experiments were conducted in 2007/2008 in the municipality of Campos dos Goytacazes (the first in the Colégio Estadual Agrícola Antônio Sarlo and the second at the Experimental Station of PESAGRO-RIO, at a distance of $10 \mathrm{~km}$ from each other) and a third was established more than $110 \mathrm{~km}$ away in Itaocara (Ilha do Pomba, Experimental Station of PESAGRO-RIO), which are hereafter referred to as E1, E2 and E3, respectively.

A randomized block design with seven replications was used. Each plot consisted of one 5-m row spaced 0.90 $\mathrm{m}$ away from the next and $0.20 \mathrm{~m}$ between plants, totaling 25 plants per plot. Three seeds were sown per hole at a depth of $0.05 \mathrm{~m}$, and thinned to one plant per hole 21 days after emergence. The cultural treatments were performed as recommended by Sawazaki (2001).

Eleven characteristics were evaluated at the plot level, namely: mean plant height (MPH), mean insertion height of the first ear (MEH), proportion of lodged plants (PLP), mean final stand (MSt) prolificacy (PROLIF), mean ear weight (MEW), grain yield (GY), mean number of days to flowering (FLOR), mean weight of 100 grains (W100), popping expansion (PE), and expanded volume of 100 grains (V100).

\section{Molecular descriptor}

The total cellular DNA was extracted from young leaves using the method described by Doyle and Doyle (1990) with some modifications, according to Daher et al. (2002). After extraction, DNA was quantified in 1\% agarose gel. The marker used was 'High DNA Mass Ladder' (Invitrogen, USA). The gel was stained with a mixture of 'blue juice' $6 \mathrm{X}$ ( $0.4 \mathrm{ml}$ 10X TAE, $0.5 \mathrm{M}, 0.2 \mathrm{ml} 10 \% \mathrm{SDS}, 0.2$ $\mathrm{ml}$ bromophenol blue, $7.0 \mathrm{ml}$ glycerol; $1.7 \mathrm{ml}$ sterile water) with 'GelRed 5X (1 mL of GelRed 10,000 $\mathrm{x}$ in DMSO $0.5 \mathrm{~mL}$ : $2 \mathrm{~mL}$ ultrapure water) at a ratio of 1:1, and visualized by the MiniBis Pro system.

A total of 15 ISSR primers (Inter simple sequence repeat), namely $(\mathrm{CT})_{8} \mathrm{RC}$; $(\mathrm{CT})_{8} \mathrm{TG} ;(\mathrm{GA})_{8} \mathrm{~T} ;(\mathrm{GA})_{8} \mathrm{YC}$; $(\mathrm{CTC})_{5} \mathrm{RC} ;(\mathrm{GTC})_{6},(\mathrm{GA})_{6} \mathrm{CC} ;(\mathrm{GT})_{6} \mathrm{CC},(\mathrm{CAC})_{3} \mathrm{GC}$, $(\mathrm{AG})_{8} \mathrm{YT},(\mathrm{AC})_{8} \mathrm{CT},(\mathrm{AC})_{8} \mathrm{YG},(\mathrm{CT})_{8} \mathrm{RG},(\mathrm{GGAT})_{3} \mathrm{GA}$, and $(\mathrm{GAA})_{6} \mathrm{AA}$.

The PCR amplification reactions were performed according to Zietkiewicz et al. (1994) with modifications, in a final volume of $20 \mathrm{~mL}$ containing the following reagents at the concentrations: $2 \mu \mathrm{L} 10 \mathrm{X}$ buffer $(500 \mathrm{mM} \mathrm{KCl}, 100$ $\mathrm{mM}$ Tris-HCl pH 8.4, $1 \%$ Triton X-100), $2 \mathrm{~mL} 25 \mu \mathrm{M} \mathrm{MgCl}_{2}$, $1.6 \mathrm{~mL} 2 \mathrm{mM}$ dNTPs, $1 \mathrm{~mL}$ DMSO (Dimethyl sulfoxide), $1.8 \mu \mathrm{L} 0.5 \mathrm{mM}$ primer (RW Genes and Invitrogen) $0.12 \mathrm{~mL}$ 5U Taq DNA polymerase and $2 \mathrm{~mL}$ of $5 \mathrm{ng}$ genomic DNA, completing the final volume with ultrapure water.

\section{Data analysis}

An individual analysis of variance was performed for the agronomic data and, a posteriori, the combined analysis of variance, using the characteristics of which the ratio between the highest and lowest residual mean square was less than 7:1. The combined ANOVA was implemented according to the statistical model 
Magnitude of the genetic base of commercial popcorn and in recommendation in Brasil

Table 1. Popcorn genotypes recommended and in the final test phase in Brazil, with the respective origins

\begin{tabular}{cccc}
\hline Cultivars & Type & Origin & Developed by \\
\hline Zélia & Triple-cross hybrid & Lines & Pioneer Hi-bred \\
Jade & Triple-cross hybrid & Lines & Pioneer Hi-bred \\
UFVM2 Barão de Viçosa & Variety & Brazilian variety & Universidade Federal de Viçosa \\
Viçosa & Variety & Brazilian variety & Universidade Federal de Viçosa \\
Beija-Flor & Variety & Brazilian variety & Universidade Federal de Viçosa \\
IAC 112 & Single-cross hybrid & Lines & Instituto Agronômico de Campinas, IAC \\
IAC 125 & Triple-cross hybrid & Lines & Instituto Agronômico de Campinas, IAC \\
BRS Angela & Triple-cross hybrid & Brazilian variety & Embrapa/Milho e Sorgo \\
UNB2U-C3 & Variety & Brazilian variety & Universidade Estadual do Norte Fluminense \\
UNB2U-C4 & Variety & Brazilian variety & Universidade Estadual do Norte Fluminense \\
\hline
\end{tabular}

$Y_{i j k}=\mu+R / A_{j k}+G_{i}+A_{j}+G_{i j}+\xi_{i j k}$, where $m$ is the mean; $\mathrm{R} / \mathrm{A}_{\mathrm{jk}}$ is the effect of the $\mathrm{k}^{\text {th }}$ replication within the $i^{\text {th }}$ environment; $G_{i}$ is the fixed effect of $i^{\text {th }}$ genotype; $A_{j}$ is the fixed effect of the $\mathrm{j}^{\text {th }}$ environment; $\mathrm{GA}_{\mathrm{ij}}$ is the interaction effect of $i^{\text {th }}$ genotype in the $j^{\text {th }}$ environment; and $\xi_{\mathrm{ijk}}$ is the experimental error (Cruz et al. 2004). Thereafter the genetic diversity among genotypes was analyzed by Mahalanobis' generalized distance $\left(\mathrm{D}^{2}\right)$ and UPGMA cluster analysis (Unweighted Pair-Group Method with Arithmetic Mean). For the molecular data, the Jaccard dissimilarity coefficient and UPGMA clustering were used. Pearson's correlation, together with the Mantel test with 1000 permutations (Mantel 1967), were used to assess the associations between distance matrices of agronomic and molecular data. The statistical analyses were performed using the software Genes (Cruz 2006) and R (http://www.r-project.org).

\section{RESULTS AND DISCUSSION}

\section{Agronomic traits}

Significant effects $(p<0.01)$ by the $F$ test for all traits were found for the sources of genotype and environment variation, which is an indicator of the presence of variability among the genotypes and variations in soil and climatic conditions, favoring the expression of genetic differentiation among the genotypes evaluated. For the source of variation of the GE interaction only the characteristic ear height showed no significant difference $(\mathrm{p}<0.01)$ by the $\mathrm{F}$ test. The significance of GE interaction indicates a differential response of genotypes to environmental changes (Ramalho et al. 1993). The initial perspective of consistent clusters between environments in this paper, by the simple interactions, was invalidated by the finding that the estimated correlations between distance matrices of genotypes in the field were low to medium, with lowest magnitude 0.32 , between environments $\mathrm{E} 1$ and $\mathrm{E} 3$, and the highest 0.56 ; between $\mathrm{E} 2$ and $\mathrm{E} 3$ and 0.38 between environments $\mathrm{E} 1$ and $\mathrm{E} 2$.

These different values of association between distance matrices favored the formation of distinct groups by UPGMA clustering (Figure 1). For example, in group I E1 joined the varieties UFVM2 Barão de Viçosa, Viçosa, Beija-Flor; in E2 the variety Viçosa was separated from the other genotypes and was alone in group I, in turn, UFVM2 Barão Viçosa and Beija-Flor formed group III. Viçosa and Beija-Flor were grouped together in E3, forming group III along with UNB2U-C3, but UFVM2 Barão de Viçosa participated in group IV, which also included Zélia and Jade. The clustering of UNB2U-C3 and UNB2U-C4 in all groups had been expected, since they represent a succession of recurrent selection cycles of the same population UNB-2U (Vilela et al. 2008) and since the progenies were selected at two of the environments, E1 and E3. However, the cycles C3 and C4 of UNB-2U were only grouped together in E1 and E2 (Figure 1). Therefore, it must be mentioned that in the present study, with the same type of simple interactions between environments, the clusters differed from each other.

In this sense, Cargnelutti Filho et al. (2009), when assessing the genetic diversity of 13 common bean accessions in the central depression region the State of Rio Grande do Sul, found that seven and six experiments in randomized blocks with three replications were sufficient to identify divergent cultivars by the clustering methods Ward and Tocher, respectively.

In this study with popcorn, quantitatively there were not seven experiments, however, the number of replications in the three tests was very high (seven), which certainly contributed to the adequate genotypic expression of the traits compared to experiments in similar designs with three 
TOM Paula et al.
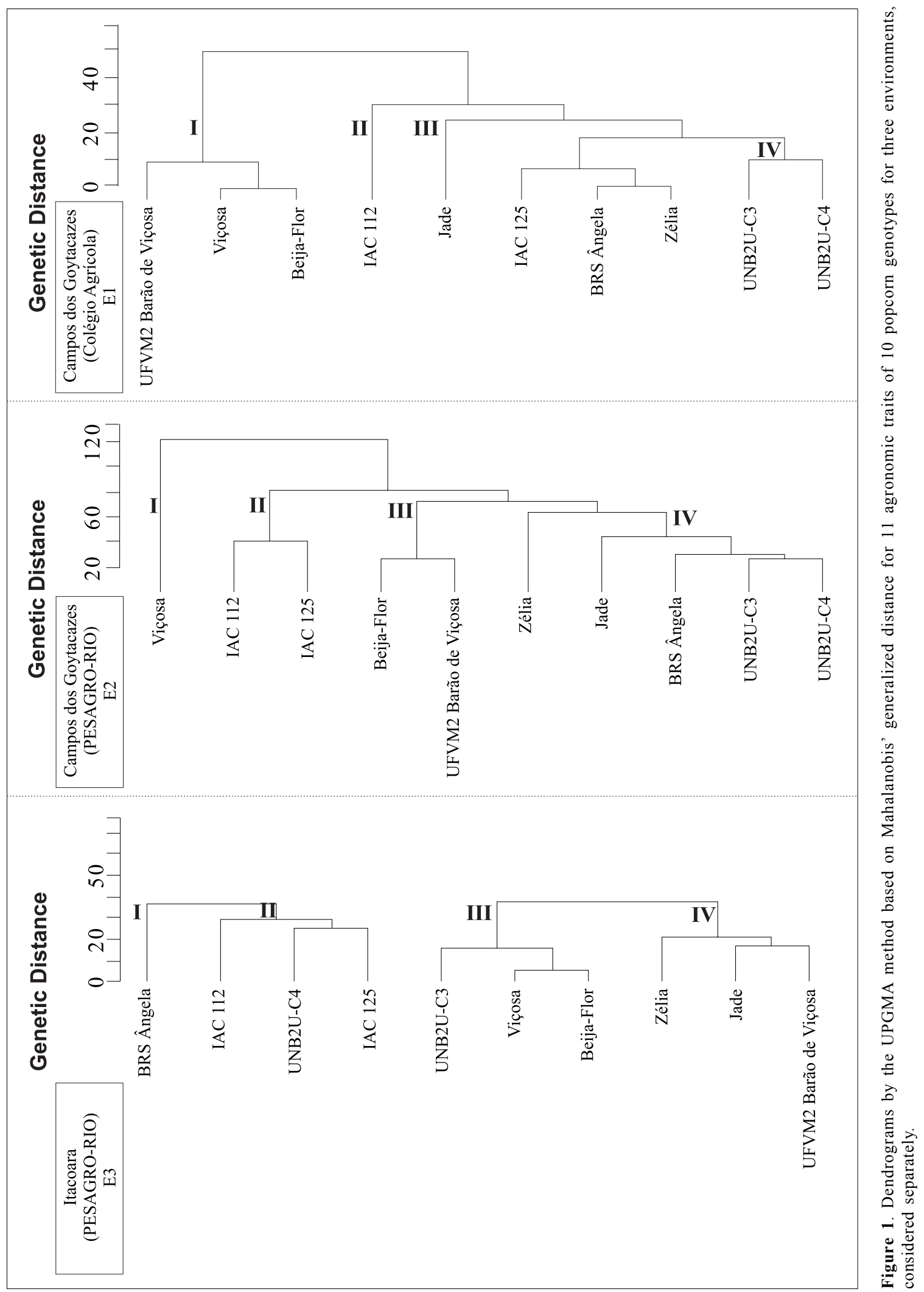
or four replications. It should not be left unmentioned that a higher number of environments increases costs. In this sense, it is worth remembering the choice strategy of environment with least interaction, used by Miranda et al. (2003), which is a valuable alternative for this study, with the purpose to understand the magnitude of the genetic basis of the genotypes evaluated and to reliably identify differing popcorn genotypes for controlled crosses.

The estimates of coefficients of environmental variation, as well as the ratio $\mathrm{CVg} / \mathrm{CVe}$ and the genotypic determination coefficient indicated $\mathrm{E} 2$ as the environment with the lowest GE interactions for most traits, except for final stand, grain yield and volume of 100 popped kernels (Table 2), and therefore as the most suited for the study of diversity.

By UPGMA clustering of genotypes in E2, the following four dissimilar groups were formed: group I (Viçosa), group II (IAC 112 and IAC 125), group III (BeijaFlor and UFVM2 Barão de Viçosa) and group IV (Zélia, Jade, BRS Angela, UNB2U-C3 and UNB2U-C4) (Figure 1). Genotypes from the same breeding programs were most similar, such as UNB2U-C3 and UNB2U-C4 of the UENF recurrent selection program and the hybrids IAC 112 and IAC 125, of the popcorn breeding program of the Instituto Agronômico de Campinas. The variety Viçosa was in a separate group since the characteristics differed greatly from the other genotypes. This is the only genotype that had not been subjected to any artificial selection processes.

By the distance matrix of the combined analysis of the environments, significant correlations $(p<0.01)$ were estimated by the Mantel test, with magnitudes of 0.69 , 0.79 and 0.80 for E1, E2 and E3, respectively. By UPGMA clustering of the combination of the three environments, the 10 genotypes were divided into four groups: Group I (Jade, Viçosa, Beija-Flor, and UFVM2 Barão de Viçosa), group II (IAC 112), group III (IAC 125, BRS Angela and Zélia) and group IV (UNB2U-C3 and UNB2U-C4) (Figure 2). These groupings were less consistent with the genealogy compared to those obtained only with the trait analysis of the genotypes evaluated in E2 (Figure 1), confirming the superior reliability of clustering of the latter environment.

\section{ISSR markers}

Each primer produced bands of varying intensity, easily detected, and nonspecific bands that were discarded. The 15 primers produced 109 bands. Of these, 70 were polymorphic, i.e., in the mean, each primer generated 4.67 polymorphic bands. The total number of polymorphic bands per primer ranged from 2 to 8 , of which primer $(\mathrm{GA})_{8} \mathrm{~T}$ was the most polymorphic. By the Jaccard matrix, the genotypes BRS Angela and IAC 125, with a distance of 0.3929 , were identified as the most distant, while the genotypes and UNB2U-C3 and UNB2U-C4 were the most similar, separated by 0.1667 . The mean distance observed between the accessions was $0.3239( \pm 0.0514)$.

The greatest genetic distance between genotypes BRS Angela and IAC 125 may be mainly due to the genotype and origin, and the variety BRS Angela, developed by Embrapa Milho e Sorgo, in six cycles of intrapapulational recurrent selection from the cross between the variety CMS-43 and population Angela (BRA 065 901), while the triple-cross hybrid IAC 125, developed by the Agronomic Institute of Campinas, was obtained from crossing IAC 112 with a synthetic variety (Pacheco et al. 2001, Rangel et al. 2008). On the other hand, the similarity of the genotypes UNB2U-C3 and UNB2U-C4 is great, since they are from the same recurrent selection program of UENF.

With a cut at a distance of 0.32 , at the point of abrupt change, four groups were formed: group I (BRS Angela), group II (Beija-Flor), group III (Viçosa-UFV) and group IV (UFVM2 Barão de Viçosa, IAC 125, Zélia, UNB2-C3, UNB2C4, IAC 112, and Jade) (Figure 3). The formation of four groups by UPGMA clustering allowed the conclusion that the width of the genetic basis of the genotypes evaluated is considerable. Moreover, the presence of released varieties in the same group, as in the case of UFVM2 Barão de Viçosa, IAC 125, Zélia and Jade, are an appeal to the few popcorn breeders in Brazil to pay particular attention to increase the genetic diversity among breeding programs conducted by public and private institutions in the country.

\section{Relationship between agronomic traits and ISSR markers}

There was practically no correlation between the distance matrix obtained by the ISSR marker with the matrices obtained by the agronomic data in E1, E2, E3 and together (E1, E2 and E3), with values of 0.0833, 0.0781, 0.0578 , and 0.0090 , respectively. This virtually zero correlation may be due mainly to differences inherent to phenotypic and molecular markers. In other words, while the ISSR markers cover a larger proportion of the genome, including coding and non-coding regions, the agronomic data are the exclusive expression of coding regions. Consequently, the molecular profile may represent regions not correlated with the agronomic traits studied (Gonçalves et al. 2008). 
TOM Paula et al.

Table 2. Estimates of the coefficient of environmental variation $(C \hat{V e})$, genetic variation $(C \hat{V g})$, of the ratio $C \hat{V g} / C \hat{V e}$ and coefficient of genotypic determination $\left(\hat{H}^{2}\right)$ for 11 traits evaluated in 10 popcorn genotypes in three environments

\begin{tabular}{|c|c|c|c|c|c|}
\hline \multirow[b]{2}{*}{ Trait s } & \multirow[b]{2}{*}{ Environments } & \multicolumn{4}{|c|}{ Genetic parameters } \\
\hline & & $C \hat{V}_{e}$ & $C \hat{V}_{g}$ & $C \hat{V}_{e} / C \hat{V}_{g}$ & $\hat{H}^{2}$ \\
\hline \multirow{3}{*}{ Mean plant height } & Campos (Colégio Agrícola) & 6.24 & 6.79 & 1.09 & 89.23 \\
\hline & Campos (PESAGRO-RIO) & 3.93 & 5.85 & 1.49 & 93.95 \\
\hline & Itaocara (PESAGRO-RIO) & 3.95 & 4.50 & 1.14 & 90.09 \\
\hline \multirow{3}{*}{ Mean insertion height of the first ear } & Campos (Colégio Agrícola) & 8.63 & 7.73 & 0.90 & 84.91 \\
\hline & Campos (PESAGRO-RIO) & 6.16 & 8.20 & 1.33 & 92.55 \\
\hline & Itaocara (PESAGRO-RIO) & 7.52 & 3.88 & 0.52 & 65.08 \\
\hline \multirow{3}{*}{ Mean proportion of lodged plants } & Campos (Colégio Agrícola) & 39.86 & 17.35 & 0.44 & 56.99 \\
\hline & Campos (PESAGRO-RIO) & 34.71 & 28.88 & 0.83 & 82.94 \\
\hline & Itaocara (PESAGRO-RIO) & 40.57 & 6.86 & 0.17 & 16.68 \\
\hline \multirow{3}{*}{ Final stand } & Campos (Colégio Agrícola) & 6.97 & 1.93 & 0.28 & 34.93 \\
\hline & Campos (PESAGRO-RIO) & 7.67 & 5.21 & 0.68 & 76.33 \\
\hline & Itaocara (PESAGRO-RIO) & 1086 & 989 & 091 & 8529 \\
\hline \multirow{3}{*}{ Prolificity } & Campos (Colégio Agrícola) & 13.91 & 6.09 & 0.44 & 57.33 \\
\hline & Campos (PESAGRO-RIO) & 9.51 & 13.44 & 1.41 & 93.32 \\
\hline & Itaocara (PESAGRO-RIO) & 21.57 & 12.33 & 0.57 & 69.59 \\
\hline \multirow{3}{*}{ Mean ear weight } & Campos (Colégio Agrícola) & 17.36 & 12.29 & 0.71 & 77.80 \\
\hline & Campos (PESAGRO-RIO) & 9.93 & 9.45 & 0.95 & 86.36 \\
\hline & Itaocara (PESAGRO-RIO) & 20.75 & 16.96 & 0.82 & 82.38 \\
\hline \multirow{3}{*}{ Mean grain yield } & Campos (Colégio Agrícola) & 14.52 & 11.60 & 0.80 & 81.71 \\
\hline & Campos (PESAGRO-RIO) & 10.58 & 8.78 & 0.83 & 82.82 \\
\hline & Itaocara (PESAGRO-RIO) & 18.74 & 16.37 & 0.87 & 84.23 \\
\hline \multirow{3}{*}{ Mean number of days to flowering } & Campos (Colégio Agrícola) & 2.61 & 1.84 & 0.70 & 77.71 \\
\hline & Campos (PESAGRO-RIO) & 2.29 & 4.78 & 2.09 & 96.82 \\
\hline & Itaocara (PESAGRO-RIO) & 3.59 & 3.49 & 0.97 & 86.86 \\
\hline \multirow{3}{*}{ Mean weight of 100 grains } & Campos (Colégio Agrícola) & 7.15 & 10.10 & 1.41 & 93.33 \\
\hline & Campos (PESAGRO-RIO) & 6.50 & 14.25 & 2.19 & 97.12 \\
\hline & Itaocara (PESAGRO-RIO) & 6.18 & 9.78 & 1.58 & 94.60 \\
\hline \multirow{3}{*}{ Popping expansion } & Campos (Colégio Agrícola) & 7.43 & 20.89 & 2.81 & 98.22 \\
\hline & Campos (PESAGRO-RIO) & 4.97 & 17.79 & 3.58 & 98.89 \\
\hline & Itaocara (PESAGRO-RIO) & 5.83 & 17.80 & 3.05 & 98.49 \\
\hline \multirow{3}{*}{ Volume of 100 popped kernels } & Campos (Colégio Agrícola) & 13.85 & 15.03 & 1.09 & 89.19 \\
\hline & Campos (PESAGRO-RIO) & 16.09 & 12.14 & 0.75 & 79.93 \\
\hline & Itaocara (PESAGRO RIO) & 855 & 844 & 099 & 8721 \\
\hline
\end{tabular}


Magnitude of the genetic base of commercial popcorn and in recommendation in Brasil

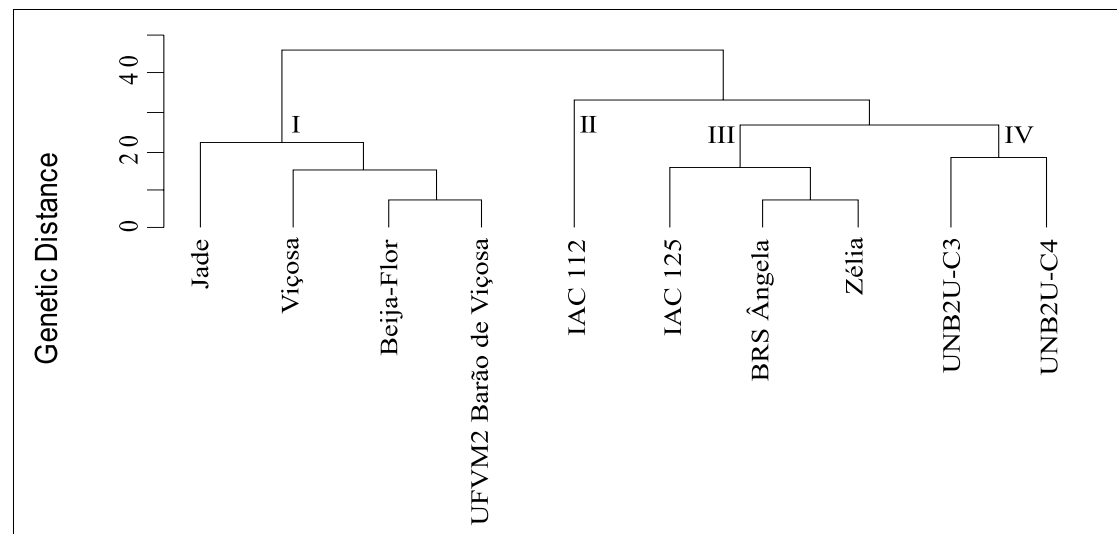

Figure 2. Dendrogram by the UPGMA method based on Mahalanobis' generalized distance for 11 agronomic traits of 10 popcorn genotypes for three combined environments.

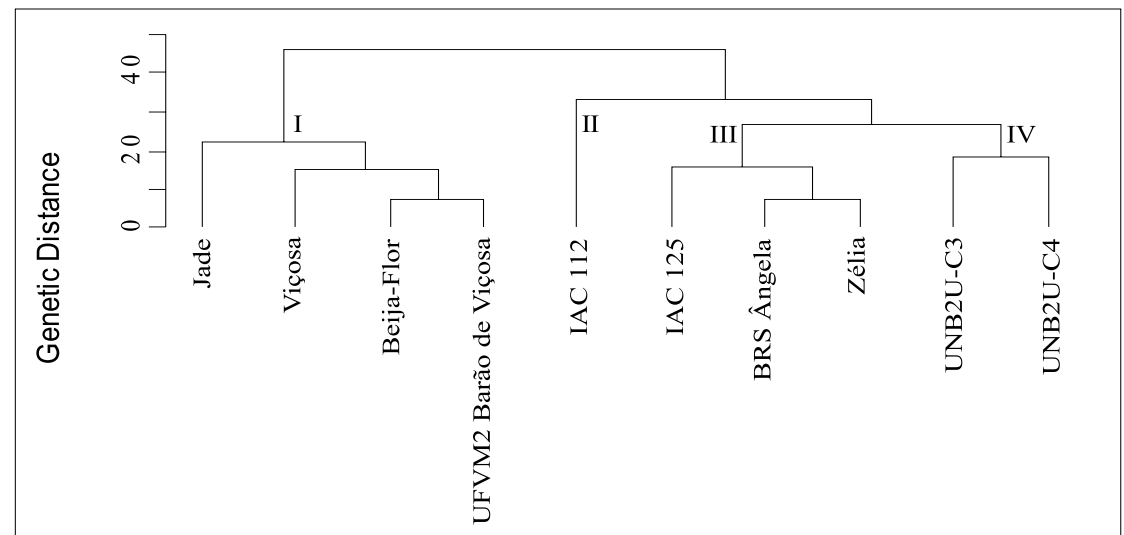

Figure 3. Dendrogram by the UPGMA method based on Jaccard's distance for ISSR markers in 10 popcorn genotypes.

\section{Amplitude da base genetica de milhos-pipoca comerciais e em recomendação no Brasil}

RESUMO - Objetivou-se neste trabalho quantificar a diversidade genética entre genótipos de milho-pipoca comerciais e em fase de recomendação no Brasil em três ambientes, utilizando 11 características agronômicas e marcador molecular do tipo ISSR. O ambiente de Campos dos Goytacazes revelou a formação de grupos que foram mais consonantes quando comparados com os outros ambientes. Nos dados moleculares verificou-se a presença de cultivares recomendadas em mesmo grupo, como ocorreu com UFVM2 Barão de Viçosa, IAC 125, Zélia e Jade. Esse resultado é um motivo de alerta para os poucos melhoristas de milho pipoca do Brasil, no sentido de promoção de maior diversidade genética entre programas de melhoramento realizados por instituições públicas e privadas no país. Verificou-se uma correlação praticamente nula entre a matriz de distância obtida pelo marcador ISSR com as matrizes obtidas pelos dados agronômicos.

Palavras-chave: Zea mays, interação genótipo versus ambiente, marcador ISSR, análise multivariada. 


\section{ACKNOWLEDGEMENTS}

The authors are indebted to Fundação de Amparo a Pesquisa do Rio de Janeiro (FAPERJ) for financial support for this study and to Coordenação de Aperfeiçoamento de Pessoal de Nível Superior (CAPES) for scholarships.

\section{REFERENCES}

Aguiar CG, Schuster I, Amaral Júnior AT, Scapim CA and Vieira ESN (2008) Heterotic groups in tropical maize germplasm by test crosses and simple sequence repeat markers. Genetics and Molecular Research 7: 1233-1244.

Amaral Júnior AT, Freitas Júnior SP, Rangel RM, Pena GF, Ribeiro RM, Morais RC and Schuelter AR (2010) Improvement of a popcorn population using selection indexes from a fourth cycle of recurrent selection program carried out in two different environments. Genetics and Molecular Research 9: 340-370.

Arnhold E, Mora F, Silva RG, Good-God PIV and Silva RG (2009) Evaluation of top-cross popcorn hybrids using mixed linear model methodology. Chilean Journal of Agricultural Research 69: 46-53.

Bracco M, Lia VV, Gottlieb AM, Hernández JC and Poggio L (2009) Genetic diversity in maize landraces from indigenous settlements of northeastern Argentina. Genetica 135: 39-49.

Cargnelutti Filho A, Ribeiro ND and Jost E (2009) Número necessário de experimentos para a análise de agrupamento de cultivares de feijão. Ciência Rural 39: 371-378.

Catapatti TR, Gonçalves MC, Silva Neto MR and Sabroza R (2008) Tamanho de amostra e número de repetições para avaliação de caracteres agronômicos em milho pipoca. Ciência Agrotecnologia 32: 855-862.

Cruz CD, Regazzi AJ and Carneiro PCS (2004) Modelos biométricos aplicados ao melhoramento genético. Editora UFV, Viçosa, $390 \mathrm{p}$.

Cruz CD (2006) Programa genes: análise multivariada e simulação. Editora UFV, Viçosa, 175p.

Daher RF, Pereira MG, Tupinambá EA, Amaral Júnior AT, Aragão WM, Ribeiro FE, Oliveira LO and Sakiyama NS (2002) Assessment of coconut tree genetic divergence by compound sample RAPD marker analysis. Crop Breeding and Applied Biotechnology 3: 431-438.

Dandolini TS, Scapim CA, Amaral Júnior AT, Mangolini CA, Machado MFPS, Mott AS and Lopes AD (2008) Genetic divergence in popcorn lines detected by microsatellite markers. Crop Breeding and Applied Biotechnology 8: 313-320.

Doyle JJ and Doyle JL (1990) Isolation of plant DNA from fresh tissue. Focus 12: 13-15.

Freitas Júnior SPF, Amaral Júnior AT, Rangel RM and Viana AP (2009) Genetic gains in popcorn by full-sib recurrent selection. Crop Breeding and Applied Biotechnology 9: 1-7.
Gonçalves LSA, Rodrigues R, Amaral Júnior AT, Karasawa M and Sudré CP (2008) Comparison of multivariate statistical algorithms to cluster tomato heirloom accessions. Genetics and Molecular Research 7: 1289-1297.

Kantety RV, Zeng X, Bennetzen JL and Zehr BE (1995) Assessment of genetic diversity in dent and popcorn (Zea mays L.) inbred lines using inter-simple sequence repeat (ISSR) amplification. Molecular Breeding 1: 365-373.

Leal AA, Mangolin CA, Amaral Júnior AT, Gonçalves LSA, Scapim CA, Mott AS, Eloi IBO, Cordovés V and Silva MFP (2010) Efficiency of RAPD versus SSR markers in determination of genetic diversity among popcorn lines. Genetics and Molecular Research 9: 9-18.

Leonello LAF, Caseta DA and Fornasieri Filho D (2009) Caracterísitcas agronômicas e qualidade comercial de cultivares de milho pipoca em alta população. Acta Scientiarum Agronomy 31: 215-220.

Li YL, Lv DB, Wang YZ, Chen SJ and Tang JH (2004) Study on the genetic diversity of popcorn inbreds and their germplasm relationship with normal corn inbreds using SSR markers. Maydica 49: 327-333.

Mantel N (1967) The detection of disease clustering and a generalized regression approach. Cancer Research 27: 209220 .

Mendes TOP, Amaral Júnior AT, Gonçalves LSA, Scapim CA, Peternelli LA, Silva VQR (2010) Pi statistics unlerlying the evaluation of stability, adaptability and relation between the genetic structure and homeostasis in popcorn. Acta Scientiarum Agronomy 32: 269-277.

Miranda GV, Coimbra RR, Godoy CL, Souza LV, Guimarães LJM and Melo AV (2003) Potencial de melhoramento e divergência genética de cultivares de milho pipoca. Pesquisa Agropecuária Brasileira 38: 681-688.

Mohammadi AS and Prasanna BM (2003) Analysis of genetic diversity in crop plants-salient statistical tools and considerations. Crop Science 43: 1235-1248.

Mora F and Scapim CA (2007) Predicción de valores genéticos del efecto de poblaciones de maíz evaluadas en Brasil y Paraguay. Agricultura Técnica 67: 139-146.

Munhoz REF, Priori AJ, Amaral Júnior AT, Scapim CA and Simon GA (2009) Genetic distances among popcorn populations based on molecular marker and the correlations with the heterosis estimates on the hybrids made by diallel analysis. Genetics and Molecular Research 8: 321-328.

Oliveira EC, Amaral Júnior AT, Gonçalves LSA, Pena GF, Freitas Júnior SP, Ribeiro RM and Pereira MG (2010) Optimizing the efficiency of the touchdown technique in ISSR markers in corn (Zea mays L.). Genetics and Molecular Research 9: 835842 .

Pacheco CAP, Gama EEG, Parentoni SN, Santos MX, Lopes MA, Ferreira AS, Fernandes FT, Guimarães PEO, Correa LA, Meirelles WF, Feldman RO and Magnavaca R (2001) BRS Angela - variedade de milho pipoca. EMBRAPA/CNPMS, Sete Lagoas, 6p. (Comunicado Técnico) 
Ramalho MAP, Santos JB and Zimmermann MJO (1993) Genética quantitativa em plantas autógamas: aplicações ao melhoramento do feijoeiro. Editora UFG, Goiânia, 271p.

Rangel RM, Amaral Júnior AT, Scapim CA, Freitas Júnior SP and Pereira MG (2008) Genetic parameters in parents and hybrids of circulant diallel in popcorn. Genetics and Molecular Research 7: 1020-1030.

Rinaldi DA, Carpentieri Pipolo V, Gerage AC, Ruas CF, Fonseca Júnior NSF, Souza A, Souza SGH and Garbuglio DD (2007) Correlação entre heterose e divergência genética estimadas por cruzamentos dialélicos e marcadores moleculares RAPD em populações de milho-pipoca. Bragantia 66: 183-192.

Santacruz-Varela A, Widrlechner MP, Ziegler KE, Alvador RJ, Millard MJ and Bretting PK (2004) Phylogenetic relationships among North American popcorns and their evolutionary links to Mexican and South American popcorns. Crop Science 44: 1456-467.

Sawazaki E (2001) A cultura do milho pipoca no Brasil. O agronômico 53: 11-13.

Scapim CA, Amaral Júnior AT, Vieira RA, Moterle LM, Teixeira LR, Viganó J and Sandoval Júnior GB (2010) Novos compostos de milho-pipoca para o Brasil. Semina 31: 321-330.
Silva TA, Pinto RJB, Scapim CA, Mangolin CA, Machado MFPS and Carvalho MSN (2009) Genetic divergence in popcorn genotypes using microsatellites in bulk genomic DNA. Crop Breeding and Applied Biotechnology 9: 31-36.

Silva VQR, Amaral Júnior AT, Scapim CA, Freitas Júnior SP and Gonçalves LSA (2010) Inheritance for economically important traits in popcorn from distinct heterotic groups by Hayman's diallel. Cereal Research Communications 38: 273-285.

Vilarinho AA, Viana JMS, Santos JF and Câmara TMM (2003) Eficiência da seleção de progênies $S_{2}$ de milho pipoca, visando à produção de linhagens. Bragantia 62: 9-17.

Vilela FO, Amaral Júnior AT, Pereira MG, Scapim CA, Viana AP and Freitas Júnior SP (2008) Effect of recurrent selection on the genetic variability of the UNB-2U popcorn population using RAPD markers. Acta Scientiarum Agronomy 30: 2530 .

Zietkiewicz E, Rajalski A and Labuda D (1994) Genome fingerprinting by simple sequence repeat (SSR) - anchored polymerase chain reaction amplification. Genomics 20: 176183. 